Technological University Dublin ARROW@TU Dublin

\title{
The impact of firm characteristics on speed of adjustment to target leverage: a UK study
}

James Fitzgerald

Technological University Dublin, james.fitzgerald@tudublin.ie

J. Ryan

University of Limerick

Follow this and additional works at: https://arrow.tudublin.ie/buschacart

Part of the Accounting Commons, Business Administration, Management, and Operations Commons, and the Finance and Financial Management Commons

\section{Recommended Citation}

J. Fitzgerald \& J. Ryan (2019) The impact of firm characteristics on speed of adjustment to target leverage: a UK study, Applied Economics, 51:3, 315-327, DOI: 10.1080/00036846.2018.1495822

This Article is brought to you for free and open access by the School of Accounting and Finance at ARROW@TU Dublin. It has been accepted for inclusion in Articles by an authorized administrator of ARROW@TU Dublin. For more information, please contact arrow.admin@tudublin.ie, aisling.coyne@tudublin.ie, gerard.connolly@tudublin.ie.

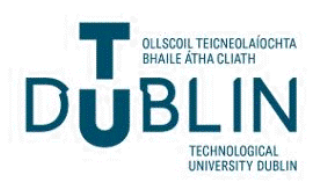




\section{The impact of firm characteristics on speed of adjustment to target leverage: a UK study}

\section{J. Fitzgerald \& J. Ryan}

To cite this article: J. Fitzgerald \& J. Ryan (2019) The impact of firm characteristics on speed of adjustment to target leverage: a UK study, Applied Economics, 51:3, 315-327, DOI: 10.1080/00036846.2018.1495822

To link to this article: https://doi.org/10.1080/00036846.2018.1495822

\section{8.}

Submit your article to this journal $\sqsubset$

山 Article views: 441

Q View related articles ๘

View Crossmark data

Citing articles: 1 View citing articles 


\title{
The impact of firm characteristics on speed of adjustment to target leverage: a UK study
}

\author{
J. Fitzgerald (1) a and J. Ryan ${ }^{\mathrm{b}}$

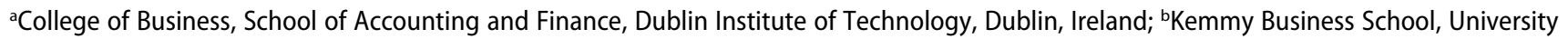 \\ of Limerick, Limerick, Ireland
}

ABSTRACT

Responding to the need to investigate heterogeneity in the speed of adjustment (SOA) to target leverage in a manner that reflects the fractional nature of leverage, we estimate SOA across subsamples of UK firms using the Dynamic Panel Fractional (DPF) estimator. Using firm characteristics to identify firms subject to varying costs of deviation from and adjustment to target leverage, we find significant evidence of heterogeneity in the speeds at which UK firms adjust to target leverage. Our results show that small, high growth and low dividend paying firms adjust to target leverage faster than their large, low growth and high dividend paying counterparts. We also find some evidence to suggest openly held firms adjust faster than closely held firms, though our results are not robust to the categorizing criterion employed or target leverage specification.

\section{KEYWORDS}

Target leverage; speed of adjustment; heterogeneity; dynamic panel fractional estimator

JEL CLASSIFICATION $\mathrm{C} 23 ; \mathrm{C} 24 ; \mathrm{G} 32$

\section{Introduction}

Since Modigliani and Miller (1958) postulated their capital structure irrelevancy theorem, a number of theories have been formulated to explain observed financing behaviour. Principal among the theories that have emerged are the trade-off theory (Robichek and Myers 1966), pecking order theory (Myers 1984) and market timing theory (Baker and Wurgler 2002). Extensive research has been undertaken to investigate the relative explanatory power of these theories, with a wide range of empirical methods and econometric models employed to test their predictions. One approach that is commonly adopted in the extant literature is to test for leverage targeting behaviour (Flannary and Rangan 2006). The trade-off theory predicts that firms that deviate from their target leverage actively adjust to target leverage by issuing, repurchasing or retiring debt and equity instruments. On the other hand, the pecking order and market timing theories imply firms' leverage ratios are merely the historical result of financing decisions motivated by the minimization of adverse selection costs and the timing of capital markets, respectively. Thus, any evidence that firms actively adjust to a target leverage ratio would provide support for the trade-off theory over the other two theories. The results of studies that adopt this approach are almost unanimousfirms actively adjust to a target leverage ratio, but are hindered in doing so by adjustment costs (Ozkan 2001; De Miguel and Pindado 2001; Fama and French 2002; Gaud et al. 2005; Leary and Roberts 2005; Flannery and Rangan 2006). Such evidence provides strong support for a dynamic version of the trade-off theory where firms adjust towards a target leverage ratio, with the time taken to reach the target, more commonly referred to as the speed of adjustment (SOA), being dependent on the relative costs of deviation from, and adjustment to, target leverage.

However, in the last decade a general consensus has been reached that deviation and adjustment costs are not homogenous across firms or through time. The aim is no longer to determine whether or not the average firm adjusts to a target leverage ratio or to estimate the average SOA, but rather to identify the factors that result in different SOAs due to varying deviation and adjustment costs. This shift in approach has revealed interesting insights into leverage targeting behaviour,

CONTACT J. Fitzgerald james.fitzgerald@dit.ie C College of Business, School of Accounting and Finance, Dublin Institute of Technology, Dublin, Ireland

() 2018 Dublin Institute of Technology 
showing that SOA is likely conditional on financial status (Byoun 2008; Faulkender et al. 2012; Zhou et al. 2016), macroeconomic conditions (Cook and Tang 2010), firm characteristics (Dang, Kim, and Shin 2012; Liao, Mukherjee, and Wang 2015) and institutional settings (Oztekin and Flannery 2012). However, despite this new evidence, it is likely that the true nature of leverage targeting behaviour is yet to be revealed. Recent research indicates that commonly employed econometric methods generate biased estimates of SOA, as they do not account for the fractional nature of leverage (Chang and Dasgupta 2009; Elsas and Florysiak 2015; Dang, Kim, and Shin 2015). Thus, whilst it appears that SOA is conditional on a number of factors, the exact nature of this conditionality remains unclear. In order to address the issue of fractional dependent variables in a dynamic panel setting, Elsas and Florysiak (2010) develop the dynamic panel fractional estimator (DPF). The DPF is a doubly censored tobit estimator that facilitates the use of lagged fractional dependent variables as regressors in the presence of unobserved fixed effects and an unbalanced panel, and has been shown to be the only estimator that can reliably identify different true SOAs across sub-samples of observations (Elsas and Florysiak 2015).

Using the DPF estimator, we investigate heterogeneity in the SOA of UK quoted companies. Focusing on firm characteristics likely to result in firms facing differing deviation and adjustment costs, we estimate SOA across sub-samples of firms based on firm size, growth opportunities, dividend policy and ownership structure. Our results strongly indicate that small, high growth and low dividend paying firms adjust significantly faster than their large, low growth and high dividend paying counterparts. These results are robust to the categorizing criterion employed, as well as the set of variables used to proxy target leverage. We also find evidence to suggest openly held firms adjust to target leverage faster than closely held firms, though our findings vary with categorizing criterion and target leverage specification.

Our study makes three key contributions to the capital structure literature. Firstly, although Drobetz, Schilling, and Schroder (2015) estimate the SOA of the average UK firm using the DPF estimator, any evidence relating to heterogeneity in SOA is based on an initial aggregated sample of firms in the G7 countries. Thus, to the best of our knowledge, we are the first study to use the DPF estimator to investigate heterogeneity in SOA of UK firms. Secondly, the US and UK are both market based systems with similar legal and financial traditions, adjustment costs and adjustment benefits (Drobetz, Schilling, and Schroder 2015), and hence one would expect the SOAs in these countries to be affected by firm characteristics in a similar way. Thus, by examining the effects of firm size and growth opportunities, characteristics which Elsas and Florysiak (2011) examine in their US study, we generate new comparable evidence on the ability of these characteristics to explain heterogeneity in SOA. Finally, apart from using firm size and growth opportunities to identify firms subject to varying deviation and adjustment costs, we also categorize firms into subsamples based on dividend policy and ownership structure. Again to the best of our knowledge, we are the first study to investigate the effects of these characteristics on firms' SOA when using the DPF estimator, and thus we significantly add to the growing body of evidence in relation to heterogeneity in SOAs.

The remainder of this paper is structured as follows: Section II presents the dynamic partial adjustment model, reviews the extant literature relating to heterogeneity in SOA and outlines the key features of the DPF estimator. Section III outlines the salient features of our dataset and discusses the method used to investigate heterogeneity in SOA. Section IV discusses the findings of our study and Section V concludes.

\section{Dynamic partial adjustment and the extant literature}

\section{The model}

Over the last half century, the capital structure literature has focused on forming theories that can explain observed variation in firms' capital structures, and subsequently assessing the validity of these theories via econometric tests of their empirical predictions. One approach that has come to dominate recent empirical studies is the 
dynamic partial adjustment (DPA) model. This model assumes that a firm has a unique target leverage ratio in a given time period, and that it actively adjusts its leverage ratio each time period such that the actual leverage ratio is as close as possible to the target leverage ratio. These assumptions imply that the change in a firm's actual leverage ratio in a given time period can be expressed as:

$$
D_{i t}-D_{i t-1}=\lambda\left(D_{i t}^{*}-D_{i t-1}\right)
$$

where $D_{i t}^{*}$ and $D_{i t}$ are the target and actual leverage ratios of firm $i$ at time $t$, respectively, $D_{i t}-$ $D_{i t-1}$ is the change in actual leverage ratio from time $t-1$ to time $t, D_{i t}^{*}-D_{i t-1}$ is the required change in the actual leverage ratio from time $t-1$ to time $t$ to achieve the target leverage ratio, and $\lambda$ represents the fraction of the required change in the actual leverage ratio achieved. In the traditional static trade-off model the firm is assumed to always be at its optimum leverage ratio, and thus the change in the leverage ratio in any period exactly equals the required change, implying $\lambda=1$. However, if firms face adjustment costs when seeking to achieve target leverage, the actual change will be a fraction of the required change, and $\lambda$ will lie between 0 and 1 . Therefore, $\lambda$ represents the speed at which a firm adjusts to its target, and its magnitude is dependent on the relative costs of deviating from and adjusting to target leverage. Bringing all $D_{i t-1}$ over to the RHS and factoring out $D_{i t-1}$ results in:

$$
D_{i t}=(1-\lambda) D_{i t-1}+\lambda D_{i t}^{*}
$$

Thus, the model to be tested states that the leverage ratio of firm $i$ in time $t$ is a function of a firm's leverage ratio in time $t-1$ and its target leverage ratio in time $t$. As a firm's target leverage is unobservable, the common approach is to model it as a function of a set of observable lagged firm characteristics, as well as unobservable firm-specific time-invariant effects. This can be expressed as:

$$
D_{i t}^{*}=\sum_{k=1}^{k} \beta_{k} x_{k i t-1}+\alpha_{i}+u_{i t}
$$

where $\sum_{k=1}^{k} \beta_{k} x_{k i t-1}$ is a set of $k$ firm characteristics for firm $i$ at time $t-1, \alpha_{i}$ represents unobserved firm-specific time-invariant effects, and $u_{i t}$ is an error term. Substituting Equation 3 into Equation 2 and multiplying out results in:

$$
D_{i t}=(1-\lambda) D_{i t-1}+\lambda \sum_{k=1}^{k} \beta_{k} x_{k i t-1}+\lambda \alpha_{i}+\lambda u_{i t}
$$

This is the standard version of the DPA model estimated in the extant literature, where one minus the coefficient on the lagged dependent variable implies the speed at which firms on average adjust to target leverage. Examples of early studies estimating this model include De Miguel and Pindado (2001), Ozkan (2001), Gaud et al. (2005) and Flannery and Rangan (2006).

\section{Heterogeneity in SOA}

In early studies (De Miguel and Pindado 2001; Ozkan 2001; Gaud et al. 2005), the purpose of estimating Equation 4 is to test the core hypothesis of the dynamic trade-off theory that firms actively adjust to a target leverage ratio. The approach adopted is to use a single large aggregated sample of firm-year observations, where the SOA estimated reflects the average speed at which firms adjust to target leverage. However, given the growing consensus that the factors motivating firms' financing decisions are unlikely to be homogenous across firms or through time (Myers 2001; Frank and Goyal 2009), researchers have begun investigating whether or not SOA is also heterogeneous due to variations in deviation and adjustment costs.

One of the earliest studies to investigate heterogeneity in SOA is Drobetz and Wanzenried (2006), which models $\lambda$ as a function of the magnitude of deviation from target leverage, firm size, growth opportunities, and macroeconomic conditions. The study finds SOA to be positively related to the magnitude of deviation from target leverage, growth opportunities, and macroeconomic conditions, with firm size having a mixed impact on SOA. The authors argue that these relationships are due to lower adjustment costs arising from economies of scale, growing firms having greater scope to alter the composition of their financing, and better macroeconomic conditions 
providing easier access to capital markets. Examining the combined effect of financial status and deviation from target leverage, Byoun (2008) argues that firms with large financial surpluses or deficits are in convenient positions to adjust to target leverage and hence will exhibit a faster SOA. However, whether firms are over or under leveraged should influence the effect financial status has on SOA due to the relative costs of adjusting debt and equity levels. Byoun finds that firms that are above target leverage adjust faster than those below target leverage, and that within these two groups of firms, firms above target leverage with a surplus adjust faster than those with a deficit, whilst firms below target leverage with a deficit adjust faster than those with a surplus.

Focusing on the effect of macroeconomic conditions on SOA, Cook and Tang (2010) find strong evidence that adjustment speeds vary through time as access to capital markets changes. Using a number of variables to distinguish between good and bad macroeconomic states, the study finds firms adjust to target leverage faster in good states than in bad. Furthermore, using bond ratings as a proxy for financial constraint, it finds financially constrained firms adjust more slowly than their unconstrained counterparts. Oztekin and Flannery (2012) use data from 37 countries to investigate whether differences in SOA can be explained by variations in legal, institutional and financial environments. They find that firms in common law countries adjust faster than those in civil law countries due to stronger protection of investors' rights, whilst firms in countries with market-based financial systems, or with more highly developed financial systems, adjust faster due to lower transaction costs.

Dang, Kim, and Shin (2012) investigate heterogeneity in SOA using financial status, financing activities and firm characteristics to proxy for the deviation and adjustment costs firms face. Firms with large financing imbalances, large investment or low earnings volatility are found to adjust faster than firms with opposing characteristics. Fastest SOAs are observed in firms that are over-levered with a financial deficit, deviate from target leverage by a large amount, and adjust through equity issues rather than debt retirements. Adopting a similar approach to Byoun (2008), Faulkender et al. (2012) investigate the joint impact of firms' cash flows and deviation from target on their SOA. They argue that adjustment is driven not only by transactions costs, but also by a firm's incentive to access capital markets, where investment opportunities prompt firm's to seek financing, and excess internal funding provides firms with the opportunity to repurchase and retire equity and debt. The results show that firms with near zero cash flow realizations adjust relatively slowly, whilst firms with deficits and surpluses in excess of their deviations from target leverage adjust two to three times faster.

Taking a different approach to previous studies, Zhou et al. (2016) argue that SOA is not only driven by the cash flow benefits and costs associated with achieving target leverage, but also by the impact on a firm's cost of capital. The study focuses on the relationship between a firm's implied cost of equity and its deviation from target leverage, and the sensitivity of this relationship to the scale of the deviation. It finds that deviation from target leverage is positively related to a firm's implied cost of equity, whilst firms whose implied cost of equity is highly sensitive to the scale of deviation adjust to target leverage at a faster rate.

\section{Fractional nature of leverage}

In order to estimate SOA and investigate heterogeneity in SOA arising from differential deviation and adjustment costs, most prior studies estimate Equation 4, or a variation of it, using a variety of estimators designed to address the econometric issues associated with estimating the DPA model. These issues include the presence of unobserved firm fixed-effects, the inclusion of the lagged dependent variable as an explanatory variable, and an unbalanced panel dataset (Drobetz, Schilling, and Schroder 2015). However, one issue that until recently has failed to be adequately addressed is the fractional nature of leverage. By definition, a firm's leverage ratio, as measured by its debt to value ratio, is bounded between 0 and 1 . Chang and Dasgupta (2009) argue that standard estimators commonly used to measure SOA fail to take this into account, resulting in SOA estimates 
that may be severely biased. This argument is supported by Elsas and Florysiak (2015) and Dang, Kim, and Shin (2015), where the biased nature of commonly used estimators is demonstrated using both simulated and actual data. Furthermore, Elsas and Florysiak (2015) show that standard estimators cannot be used to observe unique SOAs when different true SOAs exist across sub-samples of observations, and thus are unsuitable for investigating heterogeneity in SOA.

To enable lagged fractional dependent variables be used as regressors in a dynamic panel setting, Elsas and Florysiak (2010) develop the Dynamic Panel Fractional estimator (DPF). The DPF is a doubly censored tobit estimator which uses a latent variable approach to address the issue of fractional dependent variables, and specifies a conditional distribution for the unobserved firmfixed effects to allow for unbalanced panels. The observable doubly censored dependent variable, say a firm's leverage ratio in time $t$, is given by:

$$
\left\{\begin{aligned}
0 & \text { if } D_{i t}^{\#} \leq 0, \\
D_{i t}^{\#} & \text { if } 0<D_{i t}^{\#}<1, \\
1 & \text { if } D_{i t}^{\#} \geq 1 .
\end{aligned}\right.
$$

where $D_{i t}^{\#}$ is the unobserved latent variable. Elsas and Florysiak (2015) suggest that in relation to a firm's leverage ratio, this latent variable can be interpreted as a firm's debt capacity, where debt capacity can exceed $100 \%$ when highly profitable firms have not fully exploited the tax deductibility of interest payments, and can be negative if firms face high agency costs and information asymmetry. Using both simulated and actual data, Elsas and Florysiak (2015) demonstrate that the DPF estimator is robust to the bias associated with other estimators, and is capable of identifying different true SOAs across sub-samples of observations.

\section{SOA heterogeneity and the DPF estimator}

Since Elsas and Florysiak (2010) developed the DPF estimator, studies have begun using it to investigate heterogeneity in SOA. Using US data, Elsas and Florysiak (2011) compare SOA across sub-samples of firms that differ in terms of general firm characteristics, financial status and default risk. They find that small and high growth firms adjust faster than their counterparts, and similar to prior studies, that the magnitude of the deviation from target leverage is positively related to SOA. In a study of the G7 countries, Drobetz, Schilling, and Schroder (2015) examine the role of macroeconomic conditions on firms' SOA. Their results indicate that variations in adjustment costs due to changing macroeconomic conditions and differing financial systems result in firms adjusting to target leverage at varying speeds. Specifically, firms in market-based economies are found to adjust faster than those in bank-based countries, whilst adjustment is slowest in recessionary periods. Finally, Ashan and Qureshi (2017) investigate the impact of financial liberalization on the SOA of Pakistani firms, and find significantly faster adjustment to target long-term debt-to-asset ratios post financial liberalization.

It is within this strand of the capital structure literature that out study is situated, and we specifically aim to extend the work of Elsas and Florysiak (2011) and Drobetz, Schilling, and Schroder (2015) in two ways. First, by analysing the impact of firm size and growth opportunities on the SOA of UK firms when using the DPF estimator, we look to build on the evidence generated by Drobetz, Schilling, and Schroder (2015) in relation to the average SOA of UK firms, whilst also supplementing the findings of Elsas and Florysiak (2011). Secondly, by using dividend policy and ownership structure as determinants of adjustment and deviation costs, we seek to provide new evidence in relation to firms' adjustment processes.

\section{Data, variables and heterogeneity}

\section{Data}

Our sample is sourced from DataStream, and is comprised of UK listed firms for which relevant data is available between 01/01/1996 and 31/12/ 2015. Following almost all studies on capital structure, financial institutions and utilities are excluded, and to minimize the effect of outliers, variables are winsorized at the $1 \%$ level at both ends of their distributions. ${ }^{1}$ Observations with values for total assets less than $£ 1,000,000$ are

\footnotetext{
${ }^{1}$ We do not winsorize our R\&D dummy variable as it is a binary variable.
} 
dropped to prevent very small firms overly influencing our results, whilst firms must have a minimum of two consecutive observations due to the use of the lagged dependent variable as a regressor. As the DPF estimator requires an initial leverage value to be identifiable, we require all observations within firms to be consecutive. For each firm we keep the longest run of consecutive observations and drop all other observations. Finally, we drop observations with missing data for any of our variables. The final dataset is an unbalanced panel of 15,669 firm-year observations across 2111 firms.

\section{Variables}

Leverage is measured as the ratio of a firm's bookvalue total debt to book-value total assets. We use book-value rather than market-value of total assets as the denominator in the leverage ratio for two reasons. First, Beattie, Goodacre, and Thompson (2006) find that $83 \%$ of UK finance directors who measure financial leverage do so using bookvalues, suggesting leverage targeting behaviour in UK firms should be investigated using a bookvalue based measure of leverage. Secondly, market-value based measures of leverage are affected by equity market shocks over which firms have little or no control, potentially leading to spurious inferences in relation to SOA. Furthermore, Huang and Ritter (2009) suggest that if firms' market-value leverage ratios increase due to a stock market shock, and stock prices either subsequently recover and firms remain in the sample, or do not and firms drop out due to financial distress or takeover, the estimated SOA may be artificially inflated. Indeed, a number of existing studies estimate SOAs using both book-value and market-value leverage ratios, and whilst some studies find little difference between the SOAs estimated using the two leverage measures (Faulkender et al. 2012; Oztekin and Flannery 2012; Dang, Kim, and Shin 2015; Elsas and Florysiak 2015), others find notably faster adjustment speeds when leverage is measured in market terms (Gaud et al. 2005; Huang and Ritter 2009; Drobetz, Schilling, and Schroder 2015).

In relation to measuring target leverage, we employ 8 explanatory variables which collectively proxy for a firm's target debt-to-value ratio. Similar to Flannery and Rangan (2006), these variables are; firm size, asset tangibility, profitability, growth opportunities, research and development, a dummy variable indicating whether or not research and development costs are reported in the income statement, non-debt tax-shields and annual industry median leverage. Table 1 provides definitions of the dependent and explanatory variables employed, and Table 2 presents descriptive statistics for all variables.

\section{Heterogeneity in SOAs}

As discussed previously, a number of factors have been used in the extant literature to categorize observations into sub-samples across which SOA is likely to differ due to varying deviation and adjustment costs. Following Elsas and Florysiak (2011), we explore heterogeneity in the SOA of UK firms using four firm characteristics as categorizing variables. Our choice of firm characteristics is based on the fact that each one potentially

Table 1. Variable definitions.

\begin{tabular}{|c|c|c|}
\hline Variable & $\begin{array}{l}\text { Abbreviated } \\
\text { Name }\end{array}$ & Definition \\
\hline Leverage & lev & The ratio of total debt to total assets. \\
\hline Firm Size & size & The natural log of total assets. \\
\hline Asset Tangibility & tang & The ratio of net property, plant and equipment to total assets. \\
\hline Profitability & roa & The ratio of EBIT to total assets. \\
\hline Growth Opportunities & $m t b$ & The ratio of market value ordinary shares + total debt + book value preference shares to total assets. \\
\hline Research and Development & rnd & The ratio of research and development expenditure to total assets. \\
\hline R\&D Dummy & rnddum & $\begin{array}{l}\text { A dummy variable that takes a value of } 0 \text { when a firm reports research and development expenditure } \\
\text { and } 1 \text { otherwise. }\end{array}$ \\
\hline Non-Debt Tax-Shields & ndts & The ratio of depreciation, depletion and amortization to total assets. \\
\hline Industry Median Leverage & indlev & $\begin{array}{l}\text { The industry median leverage in a given year. Industry is defined using DataStream datatype INDUSTRY } \\
\text { GROUP. }\end{array}$ \\
\hline
\end{tabular}

This table lists and defines the dependent variable and the variables used to proxy a firm's target leverage. 
Table 2. Descriptive statistics.

\begin{tabular}{lccccc}
\hline & Minimum & Maximum & Median & Mean & Standard Deviation \\
\hline lev & 0 & 0.8517 & 0.1213 & 0.1669 & 0.1795 \\
size & 14.15 & 22.88 & 17.46 & 17.63 & 1.896 \\
tang & 0.0003 & 0.9317 & 0.1530 & 0.2413 & 0.2443 \\
roa & -1.5011 & 0.3683 & 0.0523 & -0.0280 & 0.2831 \\
mtb & 0.2314 & 11.34 & 1.0647 & 1.6387 & 1.7611 \\
rnd & 0 & 0.4711 & 0 & 0.0292 & 0.0787 \\
rnddum & 0 & 1 & 1 & 0.6826 & 0.4655 \\
ndts & 0.0001 & 0.2336 & 0.0369 & 0.0457 & 0.0399 \\
indlev & 0 & 0.4362 & 0.1526 & 0.1490 & 0.0905 \\
\hline
\end{tabular}

Statistics are calculated having winsorized all variables, except rnddum, at the $1 \%$ level at both ends of their distributions. Statistics are based on the full sample of 15,669 firm-year observations.

proxies for either the deviation or adjustment costs firms incur, and thus if heterogeneity in SOA is present, categorizing firms based on these characteristics should make it observable. Similar to Elsas and Florysiak (2011), we do not formulate testable hypotheses with regards the exact nature of the heterogeneity revealed by these characteristics, but rather we identify the net effect they have on firms' SOA via the variation in net deviation and adjustment costs they reveal. The four firm characteristics we use as categorizing variables and the justifications for their use are as follows:

Firm size: Due to more diversified operations and fewer information asymmetry problems, larger firms are expected to have greater access to capital markets (Antoniou, Guney, and Paudyal 2008). Furthermore, if security issuance costs involve a fixed cost component, larger firms should benefit from economies of scale when adjusting to target leverage (Drobetz and Wanzenried 2006). Thus, one would expect larger firms to adjust to target leverage at a faster rate. However, given that smaller firms are at greater risk of financial distress and are more opaque, they potentially face higher costs of deviating from target leverage and may exhibit faster SOA (Elsas and Florysiak 2011).

Growth opportunities: High transaction costs prevent firms from quickly adjusting to target leverage. However, if high growth firms are raising external finance to fund positive NPV projects, the transaction costs may be of second order importance, and firms can more freely choose the composition of the financing to achieve target leverage (Drobetz and Wanzenried 2006). On the other hand, low growth firms tend to rely more on internal financing that is limited by the funds available, and thus are more constrained in their ability to reach target leverage (Dang, Kim, and Shin 2012). These arguments suggest high growth firms will adjust faster than low growth firms. The impact of growth opportunities is likely more complex though, as Dang, Kim, and Shin (2012) note that low growth firms tend to maintain higher leverage ratios to avoid the free cash flow problem, face lower transaction costs when raising external financing due to lower information asymmetry, and face potentially high financial distress costs due to their high leverage ratios. Each of these tendencies suggests low growth firms will exhibit faster SOA than high growth firms.

Dividend policy: The degree to which a firm is financially constrained is commonly used to investigate heterogeneity in SOA (Cook and Tang 2010; Faulkender et al. 2012; Drobetz, Schilling, and Schroder 2015), where unconstrained firms are expected to adjust at a faster rate. Faulkender et al. (2012) suggest that a firm's dividend policy can proxy for degree of financial constraint, as dividend paying firms are thought to have better access to capital markets; if they did not, they would fund investment via dividend cuts. On the other hand, dividend payers may be reluctant to cut dividends to finance investment opportunities, as higher dividends help to reduce agency costs of equity (Jensen, Solberg, and Zorn 1992) and a cut in dividends may send a negative signal to investors (Lintner 1956). Thus, the costs arising from a cut in dividends may outweigh the potential benefits from achieving target leverage, suggesting firms with high pay-out ratios adjust to target leverage more slowly. We measure dividend policy as the ratio of common dividends paid to total assets. ${ }^{2}$

Ownership structure: To investigate the impact of ownership structure on adjustment to target leverage, we categorize firms as closely or openly held using the percentage of shares held by insiders. Similar to our other categorizing variables, the degree of insider ownership may affect SOA in a number of ways. Liao, Mukherjee, and Wang (2015) argue that managerial entrenchment leads

\footnotetext{
${ }^{2}$ We use total assets as the denominator rather than net income, as zero and negative values of net income would significantly reduce the number of usable observations.
} 
firms to operate with lower leverage ratios than shareholders would desire, as insiders seek to protect themselves from outside pressures. This suggests closely held firms adjust more slowly than openly held firms. Conversely, if closely held firms face significant deviation costs, insiders may choose to adjust to target leverage quite quickly, as the portion of deviation costs they bear may exceed any private benefits they get from the increased control and lower personal risk associated with low, sub-optimal leverage ratios.

When categorizing observations into sub-samples, we adopt a similar approach to that of Elsas and Florysiak (2011). First, within each time period, we find the median value of the categorizing variable, and assign each observation a value of 1 or 2 depending on whether an observation's value for the categorizing variable is below or above the within-period median value, respectively. Second, we calculate the average time-series median-based sub-sample which each firm belongs to and round this to the nearest whole number. ${ }^{3}$ The end result is that each firm, rather than each observation, is categorized as either 1 or 2 , with 1 representing firms with 'low' values for the categorizing variable and 2 representing firms with 'high' values for the categorizing variable. This sub-sampling method preserves the consecutive nature of our within-firm observations and ensures there is always an identifiable initial leverage value.

\section{Empirical results}

\section{Full sample}

Table 3 presents the results of the dynamic partial adjustment model when the full sample of firmyear observations is employed. The results are generated by estimating Equation 4 using the DPF estimator. We also include year dummies to capture the impact of unobserved time-specific firm-invariant effects on firms' target leverage ratios, though for the sake of brevity we only present the results of a Wald test of the joint significance of these year dummies.
Table 3. Results based on full sample.

\begin{tabular}{|c|c|c|}
\hline Variable & Coefficient & Standard Error \\
\hline I.lev & $0.7123^{* * *}$ & 0.0102 \\
\hline I.size & $0.0157^{* * *}$ & 0.0019 \\
\hline I.tang & 0.0173 & 0.0124 \\
\hline I.roa & $0.0126^{* *}$ & 0.0058 \\
\hline I.mtb & $-0.0019^{* *}$ & 0.0009 \\
\hline I.rnd & $0.0693^{* *}$ & 0.0293 \\
\hline I.rnddum & 0.0033 & 0.0053 \\
\hline I.ndts & $0.1005^{* *}$ & 0.0435 \\
\hline l.indlev & $-0.0800^{* * *}$ & 0.0212 \\
\hline $\mathrm{N}$ obs & \multicolumn{2}{|c|}{13,558} \\
\hline $\mathrm{N}$ firms & \multicolumn{2}{|c|}{2111} \\
\hline Wald $x^{2}$ & \multicolumn{2}{|c|}{$12,335^{* * *}$} \\
\hline Wald $x^{2}$ yrs & \multicolumn{2}{|c|}{$141^{* * *}$} \\
\hline
\end{tabular}

This table presents the results of the DPF estimator using the full sample of 15,669 firm-year observations. The number of usable observations falls to 13,558 due to the use of lagged explanatory variables. Wald $x^{2}$ represents a test of the joint significance of all explanatory variables included in the model. Wald $x^{2}$ yrs represents a test of the joint significance of all year dummies only. ${ }^{* * *},{ }^{* *}$ and ${ }^{*}$ denote significance levels of $p \leq 0.01$, $p \leq 0.05$ and $p \leq 0.1$, respectively.

The statistically significant coefficient on the lagged leverage ratio implies UK firms exhibit leverage targeting behaviour, and adjust to target leverage at an average annual rate of $28.8 \%$. This is relatively close to the average UK SOA of $32 \%$ estimated by Drobetz, Schilling, and Schroder (2015), and is in a similar range to the average US SOA of $26 \%$ as estimated by both Elsas and Florysiak (2011) and Drobetz, Schilling, and Schroder (2015). In relation to the determinants of target leverage, all variables except asset tangibility and the R\&D dummy are significant at the $5 \%$ level or higher. Consistent with prior studies, size is found to be positively related to target leverage, as larger firms are less risky (Scott and Martin 1975), whilst growth opportunities is found to be negatively related to target leverage, where high growth firms maintain debt capacity for future investment needs (Myers 1984). Interestingly, the profitability and research and development coefficients are both positive.

These results suggest more profitable firms employ more debt financing as they wish to maximize the value of the debt tax-shield (Modigliani and Miller 1963), whilst firms engaged in significant R\&D activities may prefer debt over external equity as they are more subject to information asymmetry. Unusual results are observed for non-debt taxshields and industry median leverage. Trade-off theory predicts non-debt tax-shields will be negatively

\footnotetext{
${ }^{3}$ For example, if a firm's value for the categorizing variable is below the within-period median value in 1996, 1997 and 1998, the firm is assigned a value of 1 in each of these years. If its value for the categorizing variable is above the within-period median value in 1999, 2000, 2001, 2002 and 2003, the firm is assigned a value of 2 in each of these years. The time-series average of the values assigned to the firm is 1.625 , and this is then rounded up to 2 . Thus, all observations for the firm are categorized into the 'high' sub-sample.
} 
related to leverage, as firms with alternative methods of shielding tax stand to benefit less from debt financing (DeAngelo and Masulis 1980), whilst one would intuitively expect a firm's leverage ratio to be positively related to industry median leverage. It may be that our non-debt tax-shields variable is actually proxying asset tangibility, a phenomenon Bradley, Jarrell, and Kim (1984) refer to as the 'debt securibility' effect, which makes it difficult to isolate the non-debt tax-shield effect associated with depreciation of fixed assets. Our finding for median industry leverage may be due to the determinants of target leverage being lagged relative to the dependent variable. That is, whilst a firm's leverage ratio in time $t$ is likely positively related to industry median leverage in time $t$, its actual (and target) leverage ratio in time $t+1$ may be negatively related to the industry median leverage in time $t$. For example, if a firm's desire to distinguish itself as low financial risk relative to industry competitors is a significant determinant of a firm's target leverage, one would expect a negative relationship between firm leverage in time $t+1$ and industry median leverage in time $t$. Indeed, when we re-estimate Equation 4 with industry median leverage measured contemporaneously with firm leverage, the coefficient changes from significantly negative to significantly positive. ${ }^{4}$

\section{Sub-samples}

Table 4 presents results relating to heterogeneity in SOA. Again we estimate Equation 4 with year dummies using the DPF estimator, but do so separately for each sub-sample of firms. For the sake of brevity we only present coefficient and standard error estimates for the lagged leverage variable and implied SOAs. We also report the absolute difference in SOAs within sub-sample sets, and a two-tailed $\mathrm{z}$-test statistic that indicates the extent to which SOAs can be considered significantly different across 'low' and 'high' subsamples. ${ }^{5}$ All lagged leverage coefficients are significant at the $0.1 \%$ level.

In relation to the effect of firm size on SOA, the average SOAs for small and large firms are $29.8 \%$ and $24.2 \%$ respectively, and the difference in SOAs across the sub-samples is significant at the $1 \%$ level. This suggests that although small firms may face higher adjustment costs than large firms due to limited access to capital markets or the fixed cost nature of transaction costs, the significant deviation costs small firms face due to potential financial distress costs and information asymmetry result in them exhibiting faster SOA. This finding is consistent with that of Elsas and Florysiak (2011) who find a negative relationship between firm size and SOA in US firms.

With regards to SOA heterogeneity resulting from varying growth opportunities, we find high growth firms adjust to target leverage at a rate of $30.1 \%$ per annum, whilst low growth firms adjust at a much lower rate of $23.4 \%$ per annum. Again, the difference in SOAs across the sub-samples is significant at the $1 \%$ level, providing strong evidence that SOA is conditional on a firm's growth opportunities. Our findings suggest that raising finance for investment opportunities likely provides a convenient time to adjust to target leverage, as transaction costs are less important in the decision making process. On the other hand, firms with fewer investment opportunities place greater emphasis on the magnitude of adjustment costs, as leverage adjustment is potentially the sole motivation for issuing securities. Again our results are consistent with Elsas and Florysiak (2011), where a positive relationship between SOA and growth opportunities is observed.

In terms of the impact dividend policy has on leverage targeting behaviour, we find evidence to suggest that firms that pay out zero or low dividends adjust to target leverage significantly faster than high dividend paying firms. We observe SOAs of $29.1 \%$ and $23.9 \%$ in the low and high dividend paying subsamples, respectively, with the difference in SOAs across the sub-samples significant at the 5\% level. These findings are likely due to the freedom that zero or low dividend paying firms have to pursue target leverage. High dividend payers may be reluctant to lower dividend pay-out due to the role dividends play in mitigating agency costs of equity, and

\footnotetext{
${ }^{4}$ The results of our re-estimated model are available upon request.

${ }^{5}$ The $z$ test statistic is calculated as follows: $z=\frac{\beta_{1}-\beta_{2}}{\sqrt{s e \beta_{1}^{2}+s e \beta_{2}^{2}}}$, where $\beta_{1}$ and $\beta_{2}$ are the coefficients of the lagged dependent variable within each sub-sample pairing, and $s e \beta_{1}$ and $s e \beta_{2}$ are the associated standard errors.
} 
Table 4. Sub-sample results.

\begin{tabular}{lllllcc}
\hline Categorizing Variable & $\mathrm{N}$ obs & Sub-Sample & Coeff & SE & SOA & Abs Diff $z$-test \\
\hline Firm Size & 6,300 & Low & 0.7018 & 0.0161 & 0.2982 & $0.0561^{* * *}$ \\
& 7,258 & High & 0.7579 & 0.0138 & 0.2421 & 2.646 \\
Growth Opportunities & 6,611 & Low & 0.7660 & 0.0155 & 0.2340 & $0.0673^{* * *}$ \\
& 6,947 & High & 0.6987 & 0.0143 & 0.3013 & 3.191 \\
Dividend Policy & 6,002 & Low & 0.7088 & 0.0160 & 0.2912 & $0.0521^{* *}$ \\
Insider Ownership & 7,556 & High & 0.7609 & 0.0136 & 0.2391 & 2.481 \\
& 6,939 & Low & 0.6970 & 0.0137 & 0.3030 & $0.0350^{*}$ \\
\hline
\end{tabular}

This table presents the results of the DPF estimator using sub-samples of firm-year observations. $\mathrm{N}$ obs represents the number of usable firm-year observations in a given sub-sample. Sub-sample indicates whether firms are classified as having low or high values of the categorizing variables. Coeff and SE represent the coefficient estimate and standard error, respectively, of the lagged dependent variable in a given sub-sample, and SOA is the implied speed of adjustment associated with each coefficient estimate. For each sub-sample set, Abs-Diff is the absolute difference between the implied SOAs of the Low and High sub-samples, and z-test (in italics) is a test statistic indicating whether or not this difference is statistically significant. *** ${ }^{* *}$ and ${ }^{*}$ denote significance levels of $p \leq 0.01, p \leq 0.05$ and $p \leq 0.1$, respectively.

the adverse signal a cut in dividends might send to financial markets. Hence any benefit from adjusting to target leverage using funds diverted from dividends may not be sufficient to warrant adjustment. On the other hand, the benefits of adjusting to target leverage can be fully enjoyed by low dividend payers, as there are no off-setting agency costs of equity or signalling issues resulting from dividend cuts to be considered.

Our results pertaining to ownership structure show SOAs are affected by the degree to which a firm's shares are closely held, though the effect is marginal. We observe a SOA of $30.3 \%$ in openly held firms as compared to a SOA of $26.8 \%$ in closely held firms, with the difference in SOAs being significant at only the $10 \%$ level. Our results suggest closely held firms adjust to target leverage relatively slowly as a result of pursuing leverage policies that reduce insiders' personal risks rather than maximize shareholder value. In other words, the costs of deviating from target leverage, which insiders would be partially subject to, is lower than the 'adjustment costs' of operating with a leverage ratio that does not maximize insiders' personal welfare.

\section{Robustness tests}

To test the robustness of our results, we repeat our analyses using two variations of our methodology. First, our method for assigning firms to sub-samples is based on the median values of our categorizing variables. To investigate whether or not this cut-off point for low and high values of the categorizing variables is driving our results, or preventing us from observing more statistically significant differences across sub-samples, we rerun our tests using the $40^{\text {th }}$ and $60^{\text {th }}$ percentiles as lower and upper cut-off points, respectively. Second, the reliability of SOA as generated using the standard partial adjustment model is dependent on the precision with which a firm's target leverage ratio is proxied. To determine whether or not our results are driven by our choice of variables proxying for target leverage, we re-estimate SOAs using an alternative set of target leverage determinants. These are variables that have been used in the extant literature to either proxy for target leverage or investigate the determinants of capital structure in general, and are defined in Table $5 .{ }^{6}$ We also test whether the results based on this alternative target leverage specification are dependent on the use of the median value of our categorizing variables in generating sub-samples by again using the $40^{\text {th }}$ and $60^{\text {th }}$ percentiles as upper and lower cut-off points.

The results of these robustness tests are presented in Table 6. With regards to the effects of firm size, growth opportunities, and dividend policy on SOA, varying the cut-off points chosen to categorize firms into sub-samples and/or the variables used to proxy target leverage does not qualitatively change our findings. In each variation to our methodology we again observe significantly faster SOAs in small, high growth and low dividend paying firms. On the other hand, our results relating to ownership structure are clearly

\footnotetext{
${ }^{6}$ Due to data limitations relating to some of the additional variables we construct, the number of firm-year observations before accounting for the reduction due to lagged explanatory variables decreases to 14,959 .
} 
Table 5. Alternative target leverage specification.

\begin{tabular}{ll}
\hline Variable & \multicolumn{1}{c}{ Definition } \\
\hline Firm Size & The natural log of sales. \\
Capital Expenditure & The ratio of capital expenditure to total assets. \\
Profitability & The ratio of EBIT to sales. \\
Asset Intangibility & The ratio of intangible assets to total assets. \\
Liquidity & The ratio of current assets to current liabilities. \\
Effective Tax Rate & The ratio of income taxes to EBIT. In the case where EBIT is 0 or negative, the ratio is recorded as 0. \\
$\begin{array}{ll}\text { Altman's Z-Score Modified by Mackie-Mason (1990) } \\
\text { Industry Median Leverage }\end{array}$ & $\begin{array}{l}\text { (3.3EBIT + sales }+1.4 \text { retained earnings }+1.2 \text { working capital) divided by total assets. } \\
\text { The industry median leverage in a given year. Industry is defined using DataStream datatype } \\
\text { INDUSTRY GROUP. }\end{array}$ \\
\hline
\end{tabular}

This table lists and defines the variables used as alternative proxies for a firm's target leverage.

Table 6. Robustness tests.

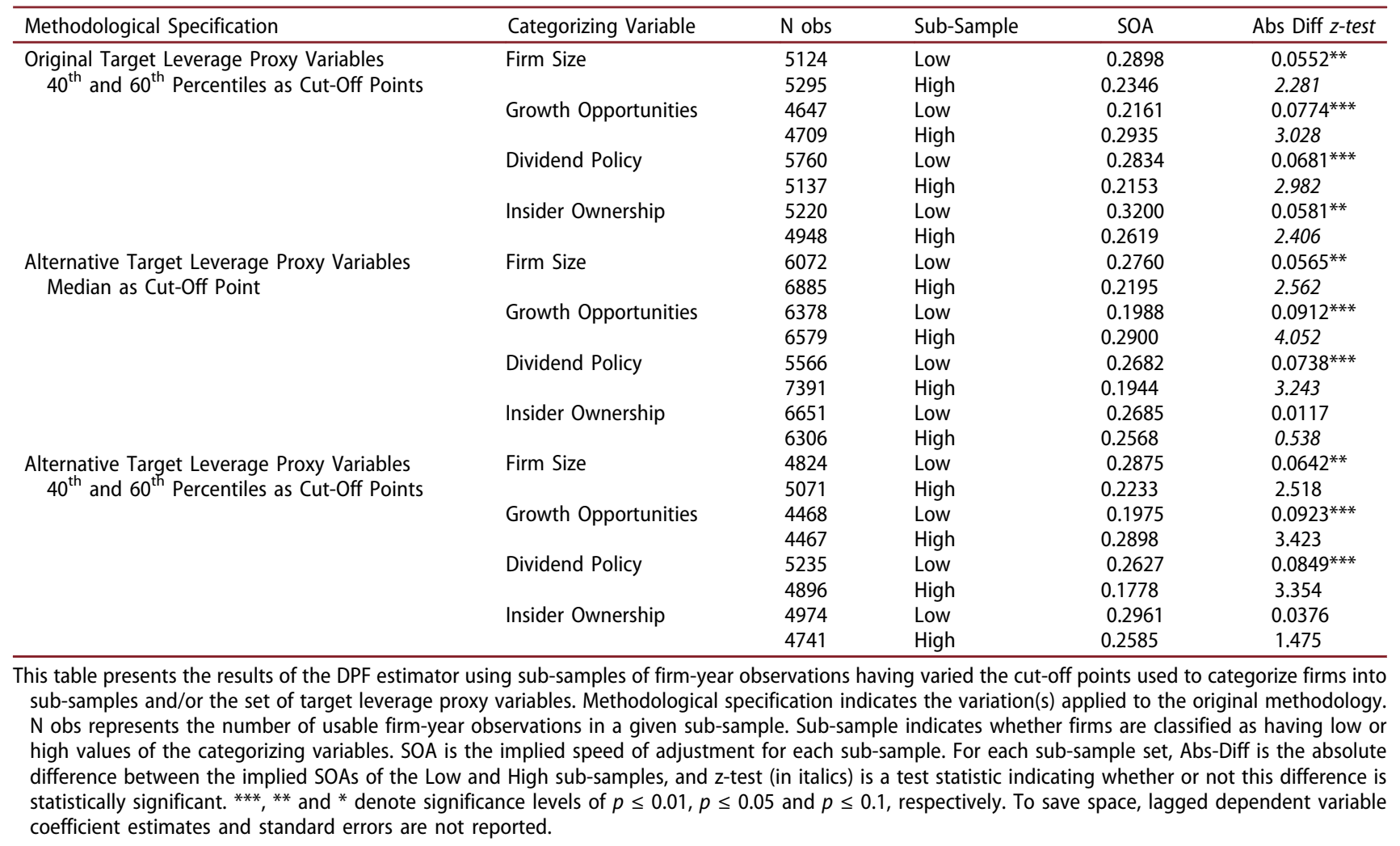

dependent on the cut-off point chosen and the target leverage specification, as differences in SOAs across openly and closely held firms vary from being significant at the $5 \%$ level to being statistically insignificant.

\section{Conclusion}

This study investigates heterogeneity in the speed of adjustment (SOA) to target leverage in UK firms. Using the Dynamic Panel Fractional (DPF) estimator which accounts for the fractional nature of leverage, we find that a firm's SOA to target leverage is dependent on firm size, growth opportunities, and dividend policy. Our results suggest that smaller firms adjust faster than larger firms due to higher costs of deviation resulting from increased risk of financial distress and/or higher degree of opacity. With regards to growth opportunities, we find a significantly faster SOA in high growth firms, which is likely due to the second order importance of transaction costs when such firms issue financing. A faster SOA is also observed when comparing zero or low dividend paying firms to high dividend paying firms, as a policy of paying little or no dividends likely enables firms to place greater emphasis on achieving target leverage rather than maintaining dividend pay-out. Finally, we find some evidence that closely held firms adjust to target leverage slower 
than their openly held counterparts, as achieving target leverage may not fit with the personal interests of insiders. Our findings relating to firm size, growth opportunities and dividend policy are robust to the cut-off point chosen for identifying firms with low and high values of the categorizing variables, as well as to an alternative target leverage specification, but our results relating to ownership structure are not.

The findings of our study have important implications for both researchers and decision makers. The robust results relating to the impact of firm size, growth opportunities and dividend policy as generated using an estimator that is unbiased in the presence of a fractional dependent variable, and the similarities of some of our results to those of Elsas and Florysiak (2011), provide strong support for the continued investigation of heterogeneity in SOA using the DPF estimator. Indeed, in a similar manner to the analysis of Pakistani firms' SOA pre and post financial liberalization as carried out by Ashan and Qureshi (2017), an interesting future experiment may be to assess the impact of 'Brexit' on the SOA of UK firms using the DPF estimator. With regards to decision makers, our results relating to dividend policy suggest that this endogenously determined firm characteristic may hinder a firm's ability to achieve target leverage, and thus should be considered in this light when firms first set there stalls out as low or high dividend payers.

\section{Disclosure statement}

No potential conflict of interest was reported by the authors.

\section{ORCID}

J. Fitzgerald (D) http://orcid.org/0000-0002-6378-9163

\section{References}

Ahsan, T., and M. A. Qureshi. 2017. "The Impact of Financial Liberalization on Capital Structure Adjustment in Pakistan: A Doubly Censored Modelling." Applied Economics 49 (41): 4148-4160.

Antoniou, A., Y. Guney, and K. Paudyal. 2008. "The Determinants of Capital Structure: Capital MarketOriented versus Bank-Oriented Institutions." Journal of Financial \& Quantitative Analysis 43 (1): 59-92.
Baker, M., and J. Wurgler. 2002. "Market Timing and Capital Structure." Journal of Finance 57 (1): 1-32.

Beattie, V., A. Goodacre, and S. J. Thomson. 2006. "Corporate Financing Decisions: UK Survey Evidence." Journal of Business Finance \& Accounting 33 (9 \& 10): 1402-1434.

Bradley, M., G. A. Jarrell, and E. H. Kim. 1984. "On the Existence of an Optimal Capital Structure: Theory and Evidence." The Journal of Finance 39 (3): 857-878.

Byoun, S. 2008. "How and When Do Firms Adjust Their Capital Structures toward Targets?" Journal of Finance 63 (6): 3069-3096.

Chang, X., and S. Dasgupta. 2009. "Target Behavior and Financing: How Conclusive Is the Evidence?" Journal of Finance 64 (4): 1767-1796.

Cook, D. O., and T. Tang. 2010. "Macroeconomic Conditions and Capital Structure Adjustment Speed." Journal of Corporate Finance 16 (1): 73-87.

Dang, V. A., M. Kim, and Y. Shin. 2012. "Asymmetric Capital Structure Adjustments: New Evidence from Dynamic Panel Threshold Models." Journal of Empirical Finance 19 (4): 465-482.

Dang, V. A., M. Kim, and Y. Shin. 2015. "In Search of Robust Methods for Dynamic Panel Data Models in Empirical Corporate Finance." Journal of Banking \& Finance 53: 84-98.

De Miguel, A., and J. Pindado. 2001. "Determinants of Capital Structure: New Evidence from Spanish Panel Data.” Journal of Corporate Finance 7 (1): 77-99.

DeAngelo, H., and R. W. Masulis. 1980. "Optimal Capital Structure under Corporate and Personal Taxation.” Journal of Financial Economics 8 (1): 3-29.

Drobetz, W., D. C. Schilling, and H. Schroder. 2015. "Heterogeneity in the Speed of Capital Structure Adjustment across Countries and over the Business Cycle.” European Financial Management 21 (5): 936-973.

Drobetz, W., and G. Wanzenried. 2006. "What Determines the Speed of Adjustment to the Target Capital Structure?" Applied Financial Economics 16 (13): 941-958.

Elsas, R., and D. Florysiak. 2010. "Dynamic Capital Structure Adjustment and the Impact of Fractional Dependent Variables." Working Paper, University of Munich.

Elsas, R., and D. Florysiak. 2011. "Heterogeneity in the Speed of Adjustment toward Target Leverage." International Review of Finance 11 (2): 181-211.

Elsas, R., and D. Florysiak. 2015. "Dynamic Capital Structure Adjustment and the Impact of Fractional Dependent Variables." Journal of Financial and Quantitative Analysis 50 (5): 1105-1133.

Fama, E. F., and K. R. French. 2002. "Testing Trade-Off and Pecking Order Predictions about Dividends and Debt." Review of Financial Studies 15 (1): 1-33.

Faulkender, M. W., M. J. Flannery, K. W. Hankins, and J. M. Smith. 2012. "Cash Flows and Leverage Adjustments." Journal of Financial Economics 103 (3): 632-646.

Flannery, M. J., and K. P. Rangan. 2006. "Partial Adjustment toward Target Capital Structures." Journal of Financial Economics 79 (3): 469-506. 
Frank, M. Z., and V. K. Goyal. 2009. "Capital Structure Decisions: Which Factors Are Reliably Important?" Financial Management 38 (1): 1-37.

Gaud, P., E. Jani, M. Hoesli, and A. Bender. 2005. "The Capital Structure of Swiss Companies: An Empirical Analysis Using Dynamic Panel Data." European Financial Management 11 (1): 51-69.

Huang, R., and J. R. Ritter. 2009. "Testing Theories of Capital Structure and Estimating the Speed of Adjustment." Journal of Financial and Quantitative Analysis 44 (2): 237-271.

Jensen, G. R., D. P. Solberg, and T. S. Zorn. 1992. "Simultaneous Determination of Insider Ownership, Debt, and Dividend Policies." Journal of Financial and Quantitative Analysis 27 (2): 247-263.

Leary, M. T., and M. R. Roberts. 2005. "Do Firms Rebalance Their Capital Structures?” Journal of Finance 60 (6): 25752619.

Liao, L. K., T. Mukherjee, and W. Wang. 2015. "Corporate Governance and Capital Structure Dynamics: An Empirical Study." The Journal of Financial Research 38 (2): 169-192.

Lintner, J. 1956. "Distribution of Incomes of Corporations among Dividends, Retained Earnings, and Taxes." American Economic Review 46 (2): 97-113.

Mackie-Mason, J. K. 1990. "Do Taxes Affect Corporate Financing Decisions?" Journal of Finance 45 (5): 1471-1493.
Modigliani, F., and M. H. Miller. 1958. "The Cost of Capital, Corporation Finance and the Theory of Investment." American Economic Review 48 (3): 261-297.

Modigliani, F., and M. H. Miller. 1963. "Corporate Income Taxes and the Cost of Capital: A Correction." American Economic Review 53 (3): 433-443.

Myers, S. C. 1984. "The Capital Structure Puzzle." The Journal of Finance 39 (3): 575-592.

Myers, S. C. 2001. “Capital Structure.” Journal of Economic Perspectives 15 (2): 81-102.

Ozkan, A. 2001. "Determinants of Capital Structure and Adjustment to Long Run Target: Evidence from UK Company Panel Data." Journal of Business Finance \& Accounting 28 (1-2): 175-198.

Oztekin, O., and M. J. Flannery. 2012. "Institutional Determinants of Capital Structure Adjustment Speeds." Journal of Financial Economics 103 (1): 88-112.

Robichek, A. A., and S. C. Myers. 1966. "Problems in the Theory of Optimal Capital Structure.” Journal of Financial and Quantitative Analysis 1 (2): 1-35.

Scott, D. F., and J. D. Martin. 1975. "Industry Influence on Financial Structure." Financial Management 4 (1): 67-73.

Zhou, Q., K. J. K. Tan, R. Faff, and Y. Zhu. 2016. "Deviation from Target Capital Structure, Cost of Equity and Speed of Adjustment." Journal of Corporate Finance 39: 99-120. 